University of Nebraska - Lincoln

DigitalCommons@University of Nebraska - Lincoln

Lilyan E. Fulginiti Publications

Agricultural Economics Department

Fall 11-26-2008

\title{
What comes first, agricultural growth or democracy?
}

Lilyan E. Fulginiti

University of Nebraska, Ifulginiti1@unl.edu

Follow this and additional works at: https://digitalcommons.unl.edu/ageconfulginiti

Part of the Agricultural and Resource Economics Commons

Fulginiti, Lilyan E., "What comes first, agricultural growth or democracy?" (2008). Lilyan E. Fulginiti Publications. 8.

https://digitalcommons.unl.edu/ageconfulginiti/8

This Article is brought to you for free and open access by the Agricultural Economics Department at DigitalCommons@University of Nebraska - Lincoln. It has been accepted for inclusion in Lilyan E. Fulginiti Publications by an authorized administrator of DigitalCommons@University of Nebraska - Lincoln. 
November 26, 2008

\title{
What comes first, agricultural growth or democracy? ${ }^{1}$
}

\author{
Lilyan E. Fulginiti ${ }^{2}$
}

\begin{abstract}
Today, the international community faces two major development challenges, how to ignite growth and how to establish democracy. Economic research has identified two plausible hypotheses regarding this association. The first hypothesis emphasizes the need to start with democracy and institutions that secure property rights. The second hypothesis emphasizes the need to start with physical and human capital accumulation. In this paper we discuss some of the econometric evidence on the relationship between institutions, human capital, and agricultural productivity growth across developed and developing countries with the objective of finding support for one or the other hypothesis. We use Barro type growth and timing regressions of agricultural growth per worker and TFP rates for a panel of countries during the 1961-2001 period. We find that most variables used in the literature to capture the effect of institutions are not independent of the process of growth. While no evidence of causation from political institutions to agricultural productivity growth is found, human capital accumulation emerges as an important source of growth.
\end{abstract}

Keywords. Agricultural productivity growth, political institutions, choice, constraints, schooling, democracy.

JEL Classification. Q10, O13, O47

\footnotetext{
${ }^{1}$ Paper prepared for seminar presentation at the Dept. of Agricultural Economics and Rural Sociology, The Pennsylvania State University, November 21, 2008.

${ }^{2}$ Professor, Department of Agricultural Economics, University of Nebraska, Lincoln.
} 


\section{What comes first, agricultural growth or democracy?}

\section{Introduction.}

Today, the international community faces two major development challenges, how to ignite growth and how to establish democracy. There is a correlation between GDP and democracy as casually can be observed by comparing Western Europe with Africa. This correlation has been a motivation for 'exporting' democracy to some countries arguing it would improve their economy. Democracy is associated with more civil and political freedoms, less abuse, respect for citizens' priorities, and in that sense, it has a value of its own. But how important is democracy for economic growth? In this paper we revisit the debate on the association between economic success and development of political institutions.

Economic research has identified two plausible hypotheses regarding this association. The first hypothesis emphasizes the need to start with democracy and institutions that secure property rights. Once political institutions are in place, investment in physical and human capital follows and with it, economic growth. The second hypothesis emphasizes the need to start with physical and human capital accumulation. As a consequence of education and capital accumulation, income growth will follow with improvement in political institutions.

These two views of economic and political development share some important similarities. They both emphasize the need for secure property rights to support investments in human and physical capital, and they both see such security as a public policy choice. The first theory, referred to as the institutional view, hypothesizes that political constraints on government are a pre-requisite to investments. The second theory, 
referred to as the development view, proposes that pro-investment policies are choices made by political leaders, whether constrained or not. Countries offered as evidence of this development strategy are China, Chile, and most East Asian tigers during the last century.

The institutional view emphasizes the need to start with democracy and other checks on government mechanisms for securing property rights, then investments in physical and human capital happen and growth follows. We find that Montesquieu (1748) and Smith (1776) as well as, more recently, Buchanan and Tullock (1962); North and Thomas (1973); and North (1981, 1990), have emphasized the importance of constraining government. Recent work on economic growth has resurrected interest on this line of thought. Work by DeLong and Shleifer (1993); Knack and Keefer (1995); Mauro (1995); Hall and Jones (1999); Acemoglu, et al. (2001, 2002, 2005, 2006, 2008); Persson and Tabellini (2006a, 2006b, 2007) has emphasized the notion that political institutions of limited government cause economic growth.

The development view emphasizes a need to start with physical and human capital accumulation for growth to follow. Then, or maybe simultaneously with, economic growth there will also be an improvement on political institutions. In this view, secure property rights, for example, are not an exclusive characteristic of a democracy. It is possible for secure property rights to be a policy choice by a pro-market dictator. In this view, countries differ in their stock of human and social capital which can be acquired through policies pursued even by dictators, and institutional outcomes depend on these endowments. Democracy and institutional improvements then are consequence of growth, not its causes. Lipset (1960), who is closely associated with this view, 
attributes this hypothesis to Aristotle. According to Lipset, the key to empowering citizens to engage with political institutions is education. It is education that allows courts to operate so that people resolve issues through negotiation and not through violence. Work by Barro (1999); Alvarez et al. (2000); Przeworski (2004a, 2004b); Djankov, La Porta, Lopez de Silanes, Shleifer (2003); Glaeser, La Porta, Lopez de Silanes, Shleifer (2004); Glaeser, Ponzetto, Shleifer (2007); Bova and Coviello (2007); Castello-Climent (2008); and Papaioannou and Siourounis (2008a, 2008b) have supported Lipset’s hypothesis, the view that growth leads to better institutions.

These two views have some points in common: an emphasis on securing property rights, and the belief that these right are a public policy choice. They differ, though, in that for the institutional view pro-investment policies and thus growth are consequences of political constraints on government, while for the development view these policies are choices of leaders who are not necessarily politically constrained.

In this paper we revisit these two general approaches and incorporate this debate into the discussions among agricultural economists measuring and trying to understand the patterns of agricultural productivity growth. More and more we encounter work in this area that has referred to 'unorthodox' models, at least from an agricultural economics perspective. In addition to traditional variables such as inputs, $R \& D$ and relative prices, models have included cultural and institutional variables in an attempt to understand the context in which the production process takes place and to understand their influence on efficiency and technical change. Given the importance of this sector in the process of growth and democratization of less developed economies, this paper will look for potential evidence supporting one or the other hypothesis. 
There are now many studies that measure, or attempt to explain, the patterns of agricultural productivity growth across countries. Some have include variables that would capture the impact of institutions. To the extensive list of seventeen studies for the period 1993-2003 found in Coelli and Rao (2005), we add the following: ${ }^{1}$ Gardner (2003); Coelli and Rao (2005); Fulginiti, Perrin, and Yu (2003); Pfeiffer (2003); Bravo-Ortega and Lederman (2004); Alauddin, Headey and Prasada Rao (2004); Bharati and Fulginiti (2007); and Ludena et al. (2007).

Only the studies by Gradner; Fulginiti, Perrin and Yu; Pfeiffer; Alauddin, Headey and Prasada Rao; and Bharati and Fulginiti include some proxy for institutional variables. Only one of these studies, the one by Alauddin, Headey and Prasada Rao, uses one of the proxies for political institutions used in the general economic growth literature mentioned above.

In this study we first introduce the alternative proxies that have been used in the general economic literature to capture the effect of political institutions and we summarize critical reviews of them. Then we use them along with estimates of partial and multifactor agricultural productivity growth ${ }^{2}$ looking for empirical evidence that would support one or the other position in this debate.

Here we are concern with the empirical evidence in agriculture, a sector that has been the source of financing for industrial development in the past and is still a most important engine of growth in many developing countries of Africa and Asia. Will the comparative evolution of the sector tell us if productivity growth happened in countries that had instituted stable democracies, or is agricultural productivity growth unrelated to 
the choice of political system? Can we establish causality, or can we just go as far as establishing correlation?

In this paper we will discuss some of the econometric evidence on the relationship between institutions, human capital, and agricultural productivity growth across developed and developing countries with the objective of finding support for one or the other view presented above. We will, in addition, try to obtain information by looking more deeply into the experience of developing countries that were 'poor' in the 1960's; a big proportion of them with important agricultural sectors, low levels of education and run by dictators. We will also present Barro’s analysis of timing that will add evidence on whether schooling or institutional outcomes come first.

Section two defines institutions, introduces proxies used in the literature, and describes new ones proposed. Section three presents Barro type growth regressions of agricultural productivity growth with and without instrumentation of the institutional proxies. In section four results of timing regressions are presented to address the question of what comes first, schooling or institutions. Section five gives a final look at the data, starting in 1960, on associations between agricultural growth, schooling, and democracy. Lastly we summarize what we learned in this exercise and suggest where this literature is heading.

\section{What are Institutions?}

The first order of study is to suggest that research in institutional economics should be explicit about how it defines institutions. We join other researchers and 
propose North’s definition as “a set of rules, compliance procedures, and moral and ethical behavioral norms designed to constrain the behavior of individuals in the interest of maximizing the wealth or utility of principals.”

Based on this definition there are two important characteristics of institutions, the existence of constraints and the durability of constraints. The legal system or electoral rules that have been used over time are examples of institutions. So to choose proxies for institutions one needs to keep in mind that they should represent constraints on governance and that they should be a durable feature of the environment.

Variables that have been used in the literature and that represent choice of policy makers rather than constraints on governance.

Recent research on economic growth has used three different sets of variables to proxy institutions. 1) Survey indicators from the International Country Risk Guide (ICRG, Political Risk Services) for the 1980’s and 1990’s. This data set was developed to assess risk for international investors. Indicators include subjective assessments of law and order, bureaucratic quality, corruption, risk of expropriation, and risk of government contract repudiation. These variables reflect what actually happened in a given year in a country, not necessarily the permanent rules of the game. They might be correlated with growth but as outcomes of a process they cannot be considered proxies for causation. ${ }^{3}$ Variables from this data set were used in the studies by Hall and Jones; and by Acemoglu et al (2001, 2002). 2) The 'government effectiveness” variable developed at the World Bank by Kaufmann, et al. (2002, 2003). This data set starts in 1996 and is composed of indices that represent aggregation of subjective assessments of institutional quality. These include "perceptions of the quality of public service provision, the quality of the 
bureaucracy, the competence of civil servants, the independence of the civil service from political pressures, and the credibility of the government's commitment to policies.” These concepts do not represent political constraints and in fact, they are the results of a process of development and once again might be correlated with growth. The study by Rodrick, Subramanian, and Trebbi uses the proxies in this data set. ${ }^{4}$ 3) The Polity IV data set, developed by the political scientists Jaggers and Marshall (2000) at the Center for International Development and Conflict Management, University of Maryland, is the best of these three data sets as it attempts, at least in theory, to measure limits of executive power and permanence. According to the authors they are concerned with capturing checks and balances in the decision making process. The criticism of this data set has to do with the volatility of the country scores and their lack of independence from election results. This index may show an improvement when elections in a country take place and are relatively free, even if there is no independence of powers in the country. This volatility contradicts the property of permanence in institutions that the proxies should capture, although it is in theory the best of the three sets.

New variables proposed to represent durable constraints on governance rather than choice of policy makers.

Glaser et al. proposed a new set of variables that would be independent because they would not represent choices made by policy makers, rather they would capture closely the permanence of constraints on governance required by North's definition of institutions. The first two are based on Persson and Tabellini's work “The Economic Effects of Constitutions" that emphasize electoral rules as constraints on the executive 
branch. The proposed proxies implemented in Beck et al., are available for 1975-2000.

They are:

1) Plurality: equals one if legislators are elected using a winner-take-all rule, otherwise zero.

2) Proportional Representation: equals one if candidates to parliament (upper and lower houses) are elected using a proportional representation system, otherwise zero.

The other two proxies are based on the work of La Porta et al. (2004) and emphasize constitutional rules of checks on the executive by the judiciary:

3) Judicial Independence: permanency in office of supreme court judges.

4) Constitutional Review: extent of judicial review of legislation.

In Table 1 we present correlations between two measures of agricultural productivity in year 2000 and the two groups of proxies, those that have been used in the literature and those that have been proposed. Table 1 indicates that the proxies used in the literature are correlated with agricultural productivity growth. This is consistent with institutions having a causal effect on productivity but also with the reverse causality. Plurality and proportional representation have a much lower correlation while judicial checks and balances are relatively uncorrelated with agricultural productivity growth.

\section{Agricultural Productivity Growth and Political Institutions.}

Barro type OLS growth regressions.

We follow the general growth literature and run a series of Barro type regressions. We use two different dependent variables measuring agricultural productivity growth. 
The first is the growth of output per agricultural worker between 1961-2000, a measure of partial productivity that is closer to the concept used in Barro type regressions for the whole economy and is obtained directly from Ludena et al. and FAO data. The alternative regression uses a multifactor productivity measure, TFP (total factor productivity) between 1970-2001, that was econometrically estimated by Alauddin et al. with a translog distance frontier fitted to a panel of countries. Productivity growth is obtained as the sum of estimated efficiency change and estimated technical change.

The frontier distance function uses as right hand side variables the quantity and quality of inputs and some institutional variables. They include the index of democracy from Polity IV as proxy for political institutions. The proxy for productivity in this case is very different than when using output per worker. First, it is supposed to measure output growth while accounting for the effects of growth in all inputs, not only labor. In addition, it attempts to correct for input quality and some institutional differences. Lastly, it is the prediction from a stochastic parametric estimation. It is expected that this measure will be very different from the simple output per worker (although this one is closer to the measure used in the macro literature, GDP per capita).

It is more and more common in the agricultural economics literature to find calculations of TFP growth obtained from radically different approaches. The literature includes Fisher and Tornquist indexes obtained directly from data, Malmquist indexes calculated from different nonparametric, nonstochastic approaches as well as from parametric and stochastic ones. It also includes productivity growth obtained from econometric estimation of production, distance, cost, revenue, and profit functions and frontiers (these ones allow for efficiency measures across countries through a rather 
complex error term.) In some cases in addition to traditional inputs, the quality and institutional variables are included in estimation. Some studies follow a two step approach and once the TFP's are estimated they are regressed on input quality and institutional variables.

The independent variables used in the cross-section analysis, following Barro, are the initial level of agricultural output per agricultural worker (1961) or the initial level of TFP (1970) depending on the regression, initial education (the 'development' variable), the share of population living in temperate zones, and the temporal averages of the eight institutional variables entered one at a time. Results in Tables 2 and 3 confirm the now standard observation that growth rates decline with initial levels of the dependent variable or that convergence is occurring. Table 2 also shows a significant influence of temperate weather. This variable is not significant when TFP growth is the dependent variable as can be seen in Table 3. Both tables show that initial level of education is a strong predictor of subsequent economic growth. These results are consistent with two alternative theories of economic growth. The endogenous growth hypothesis of Lucas which states that human capital generates significant technological externalities. The alternative is the Lipset hypothesis that states that more human capital leads to less violence and more political stability, so the externality is security as courts replace guns. Both tables show various degrees of significance of the four proxies that have been used in the literature to represent institutions and that we have referred as 'choice' variables (executive constraints, expropriation risk, autocracy and government effectiveness). In contrast, the four alternative variables (judicial independence, constitutional review, plurality, proportional representation) suggested in Glaeser et al., 
referred to as 'constraint' variables because they capture constraints on governance rather than choice of policy makers, are not significant indicating no relationship with agricultural productivity growth.

One reason that temporal average assessments of the 'choice' variables might be significant is that they might improve as the economy gets richer, in other words they are endogenous, too, and there is reversed causality. Growth regressions typically use the initial level of education (instead of the average to isolate this possibility), so in the next set of regressions below, we try using the initial level of one of the 'choice' variables, 'Executive constraints' at the beginning of the period. This variable is chosen over the other 'choice' proxies for institutions because it is clearly not a consequence of dictatorial choices (even if it has some other problems as we mentioned before). Of all the 'choice' variables used in the literature this one is closer, in theory, to representing constraints on government.

Tables 4 shows three more Barro type growth regressions of agricultural production per worker by decades and for the whole period. All three regressions share two right hand side variables, share of the population leaving in temperate zone and initial production per worker. The first regression adds initial level of the variable 'Executive constraints', the second regressions uses initial years of schooling instead, and the third includes both. Table 5 runs the same regressions but using TFP growth as a dependent variable.

Both tables show that initial period constraints on the executive have no predictive power for subsequent productivity growth, while initial human capital is a strong predictor. 
From these Barro type OLS regressions we have learned that there is no evidence of causality from the variables that have been used in the literature to reflect institutions and agricultural productivity growth. In fact the evidence indicates the possibility of reverse causality. We also have learned that the suggested alternative variables representing constitutional rules that constraint the power of the executive have no predictive power. So the OLS cross-country evidence for 1961-2000 provides no support for the claim that political institutions (democracy?) cause productivity growth, regardless of the proxy variables used to represent institutions.

\section{Instrumenting the Institutional Variables.}

The growth literature recognized that the variables used to capture institutions might in themselves be influenced by growth. To solve this problem authors have used instrumental variables. Different instruments have been used by different authors, from ethnolinguistic fractionalization as an instrument for corruption (Mauro); to distance from the equator and European languages spoken as an instrument for International Country Risk Guide variables (Hall and Jones); and origin of the legal system as instrument for legal systems (La Porta). But the most influential papers using this approach are those of Acemoglu, Johnson, and Robinson (2001, 2002) who argue that to understand each country’s political institutions, rather than looking at the laws Europeans brought we should check if they settled in the colonies. In their 2001 AER paper "The Colonial Origins of Comparative Development: An Empirical Investigation,” they hypothesize that if the Europeans settled, they brought European institutions constraining the executive, if not they instituted systems of arbitrary rule and expropriation of local resources. In their 
2002, QJE paper “Reversal of Fortune: Geography and Development in the Making of the Modern World Income Distribution,” they hypothesized that the density of the nonEuropean population in the colonies shaped settlement patterns. If the colonies were densely settled by locals, Europeans did not settle. In low density areas they settled and brought their institutions of limited government causing growth. So these authors use "settler mortality" and "indigenous population density in 1500" as instruments for modern day political institutions constraining the executive.

In Tables 6 and 7 we investigate these effects by regressing agricultural productivity in 2000 (both proxies) on instrumented average years of schooling, instrumented average "Executive constraints" and on share of the population in temperate zones in 1995. Share of the population living in temperate zones, and French legal origin are used as instruments in equations (1) and (2). Settler mortality used as an instrument in equation (1) is replaced by population density in 1500 in equation (2). While the instruments are important determinants of schooling and executive constraints in the first stage, the only statistically significant variable in the second stage is years of schooling. This confirms the importance of human capital over political institutions in predicting growth.

It is not clear what did Europeans bring with them. Did they only bring institutions of limited government? Or did they in fact, bring themselves which includes their human capital, their institutions, along with everything else they represented (according to Diamond, 'guns, germs, and steel')? So using settlement patterns as instrument for institutions is valid only if there was no influence on per capita output through other channels. If settlement patterns influence growth through channels other 
than institutions they are not 'good' instruments as they would be correlated with the error term. Perhaps when colonizers settled, they brought their know-how rather than only constraints on the executive. The effect of colonial settlement works through many channels and if this is the case, then the instrumental variables approach does not illuminate the causality discussion.

\section{What comes first, schooling or political institutions?}

One of the more robust results form the analysis above is the significance of the variable schooling that was used to capture accumulation of human capital as a proxy for the 'development' hypothesis. So as a final way to understand what came first, schooling or institutions, we follow Barro and look at timing. If institutions came first, then lagged values of political variables should predict improvements in education. If education came first, then lagged values of education should predict improvements in institutional outcomes.

First we proceed with a regression of growth in years of schooling, using five year intervals, on initial schooling, initial measures of political institutions (captured by the 'choice’ variables used in the literature) and initial level of agricultural output per worker. We also include country fixed effects. In Table 8 we see that there is convergence in schooling, and that there is a large positive effect of output per worker. It also shows no effects of any of the political institution variables on the growth of human capital.

Second, we regress changes in political institutions, in five year intervals, on the same variables: initial schooling, initial measures of political institutions, initial levels of output per worker and country fixed effects. In Table 9 we see that initial levels of 
schooling are a strong predictor for improving institutional outcomes over the next five years. Initial productivity has no predictive power.

The same regressions are repeated but instead of using initial output per worker, we use the econometrically estimated initial TFP level as a right hand side variable. The results are similar except that initial TFP level is insignificant in both regressions.

Results of these regressions are inconsistent with the hypothesis that political institutions predict subsequent improvements in human capital. In fact they support Lipset's view that high human capital leads to institutional improvement.

\section{The record on productivity growth, human capital, and institutions.}

We have examined the record on the relationship between institutions and productivity growth using econometrics. A simpler way to assess these records is by examining the raw data. The objective is to discover any regularity in the data in terms of association between agricultural growth, schooling, and democracy.

We first look at years of schooling in 1960 across political regimes measured by the average democracy score (1960-2000) from the Polity IV database. The sample median of 2.7 average years of schooling is considered an upper limit for low human capital, while high human capital is average years of schooling above 5, which is the lower limit of the $75^{\text {th }}$ percentile.

This cross classification is presented in Table 12. Each cell tells us the number of countries in 1960, in our sample with the characteristics in that cell. We are looking for evidence to answer the following questions: 
1) Are the countries with high education level the ones with stable democracy?

Yes, of a total of 18 highly educated countries, 16 are democracies.

2) Are all dictatorships poorly educated?

Yes, of a total of 21 dicatatorships, 20 are poorly educated.

This table reinforces our econometric results and lends support to Lipset's hypothesis: politics seems to have been more benign in countries with higher schooling.

The next classification, presented in Tables 13 and 14, shows average agricultural productivity growth (growth of output per worker in Table 13 and TFP growth in Table 14) for countries with different levels of schooling and political regimes. Panel A in these tables show the number of observations in each cell from a total of 2751 observations. In Panel B shows the 10-year average within country growth rate of output per worker in each cell. Panel C shows the average standard deviation of the 10 year-average growth rates across countries as a measure of volatility.

The questions to answer this time are:

1)Are the differences between educated and uneducated countries reflected in agricultural productivity growth rates? Yes, as could be seen in the tables, countries with high human capital have rates of agricultural productivity growth of approximately 3-4 percent, while rates for countries with lower human capital are in the 1-2 percent range.

2)Have stable democracies grown faster? Yes, democracies have grown slightly faster than imperfect democracies and much faster than dictatorships. 
One interesting fact to notice is that while in 1960 most poor countries were dictatorships, some have managed to grow while others have not. This indicates that some of these countries have grown even under dictatorships.

Another question of interest is : who actually leads the less educated countries over time? If we add to the classification above a third concept, the number of years leaders stayed in power, we obtain some useful information. In 66 percent (44\% for intermediate education) of the years in our sample, low education countries are led by autocratic leaders that last at least five years, and in 50 percent of the years by autocrats with tenure of at least 10 years. On the other hand the data shows that 6 percent of the years countries are led by democratic leaders with less than a 5 year tenure and in 13 percent of the years by democratic leaders with more than 5 years in power. There is a concentration of dictatorships that last for long terms. ${ }^{5}$

This information is only suggestive of associations between politics and education but it provides additional evidence that for understanding productivity growth a focus on factor accumulation might be more relevant than a focus on institutions.

\section{Conclusions and Future Directions.}

First we have settled on North's definition of institutions. Then we have learned that there are two theories to understanding the relationship between political institutions and growth. One of them, the institutional theory, hypothesizes that constraints on political institutions are necessary to establish clear property rights so that investments follow and with that growth. The other, the development theory, hypothesizes that factor accumulation follows well enforced property rights and that they could be achieved with 
or without constrained political institutions. Once factor accumulation happens, then growth happens and with it an increase in the set and an improvement in the quality of political institutions. There are two types of variables that could be used or are being used to capture the impact of institutions on productivity growth. One type reflects choices (by policy makers, dictators or not), while the other reflects constraints that have to be respected by democratic leaders. Given North's definition of institutions, the first type may confound constraints on governments with dictatorial choices, so they do not proxy institutions. Most studies have used the first type, which in some cases move (are correlated) with productivity.

We econometrically confirm the propositions found in macro studies, that initial level of human capital of a country, and the average level of its institutions over a period of time predict productivity growth over that same period. We find that initial levels of constraints on the executive do not predict productivity growth, where as initial levels of human capital do.

We find that instrumental variables used in the institutional literature (settler mortality and population density in 1500) are highly correlated with human capital. We also see that schooling performs better than institutions in explaining productivity growth in agriculture. This seems to confirm the hypothesis that Europeans brought themselves and with that not only their institutions but their know-how and 'guns, germs, and steel.'

When we look at the econometric evidence on the timing of human capital accumulation and institutional quality we find that human capital and productivity cause changes in institutions. No evidence is found on the reverse causation. 
A casual look at raw data for the countries in this study shows that most poor countries in 1960 had uneducated populations and were run by dictators and have since spent a number of years under dictators. These dictatorships had a large dispersion of growth rates. It is highly likely that the security of property that led to factor accumulation in these countries has been a result of a policy choice not of constraints on governance.

This debate is certainly not over, with recent papers in the macro literature being able only to establish association. Work by Persson and Tabellini (2006a, 2006b, 2007); Papaioannou and Siourounis (2008a, 2008b); Zajar and Zingales (2006); and Acemoglu et al. $(2006,2008)$ has emphasized the need for inclusion of more detailed and complex concepts related to institutional reform, the alternative processes of transition to democracy, and in particular the factors that affect the permanency of a democracy. The common thread between these papers is the recognition that modeling the relationship between income and political institutions is difficult with most authors tending towards a common ground in which historical factors have lead to a particular resource distribution, a particular level of human and physical capital, particular economic institutions and distribution of power that simultaneously affect the evolution of income and democracy. ${ }^{6}$

This study does not imply that institutions do not matter, as they certainly do. Rather, this study suggests that in doing research one should be careful about a clear definition and the proxies used for institutional arrangements. In terms of policy, it seems that the experience of a number of countries, captured in our econometrics, indicates that from the perspective of security of property needed for investments and growth, constraints on 
government (democratization) do not necessarily come first as such security could be a dictator's choice.

The information in this paper provides evidence that for understanding productivity growth in agriculture a focus on factor accumulation is more relevant than a focus on institutions. In particular a focus on human capital accumulation could be very promising. May be this association would serve as motivation for 'exporting' schooling rather than democracy in the hopes of improving the economies of some countries.

A cautionary last word for this study. I want to clearly state that this research does not intend to deny the merits of democracy as essential human values in their own right. It is well established that with respect to torture, death penalty, freedom of the press, religious freedom, and other human and civil rights, democracies are superior to dictatorships. 


\section{References.}

Acemoglu, Daron, Simon Johnson, and James A. Robinson. 2001. "The Colonial Origins of Comparative Development: An Empirical Investigation,” American Economic Review 91(5): 1369-401.

Acemoglu, Daron, Simon Johnson, and James A. Robinson. 2002. "Reversal of Fortune: Geography and Development in the Making of the Modern World Income Distribution,” Quarterly Journal of Economics 117(4), 1231-1294.

Acemoglu, Daron, Simon Johnson, James A. Robinson, and Pierre Yared. 2005. "From Education to Democracy?" American Economic Review Papers and Proceedings, 95 (2):44-49.

Acemoglu, Daron, Simon Johnson, James A. Robinson, and Pierre Yared. 2008. "Income and Democracy." American Economic Review, 98(3): 808-42.

Acemoglu, Daron, and James A. Robinson. 2006. Economic Origins of Dictatorship and Democracy. New York and Cambridge: Cambridge University Press.

Alauddin, M., D. Headey, and D.S. Prasada Rao. 2004. "Explaining Agricultural Productivity Levels and Growth: An International Perspective," CEPA Working Papers Series WP022005, School of Economics, University of Queensland, Australia.

Alvarez, M., J.A. Cheibub, F. Limongi and A. Przeworski. 2000. Democracy and Development: Political Institutions and Material Well-Being in the World, 19501990.Cambridge: Cambridge University Press.

Barro, Robert J. 1991 “Economic Growth in a Cross-Section of Nations,” Quarterly Journal of Economics 106(2): 407-43.

Barro, Robert J. 1997. Determinants of Economic Growth. Cambridge, MA: MIT Press.

Barro, Robert J. 1999. “Determinants of Democracy,” Journal of Political Economy 107(6-2):58-183.

Beck, T., G. Clarke, A. Groff, P. Keefer and P. Walsh. 2001. "New Tools in Comparative Political Economy: The Database of Political Institutions” World Bank Economic Review 15(1): 165-76.

Bharati, Preeti, and Lilyan E. Fulginiti, "Institutions and Agricultural Productivity in Mercosur,” pp 139-170, in Erly Cardoso Teixeira \& Marcelo Jose Baga, eds. Instituções E Desenvolvimento Econômico. Vicosa, MG, Brasil, Os Editores, 2007.

Bova, M. and D. Coviello. 2007. "Weak Instruments, and Weak Identification, on Estimating the Effects of Education on Democracy.” Economic Letters, 96: 301306.

Bravo Ortega, Claudio, Daniel Lederman. 2004. "Agricultural productivity and its determinants: revisiting international experiences.” Estudios de Economia 31 (002): 133-163

Buchanan, J. M. and G. Tullock. 1962. The Calculus of Consent, Logical Foundations of Constitutional Democracy. Ann Arbor, MI: The University of Michigan Press.

Castello-Climent, A. 2008. "On the Distribution of Education and Democracy.” Journal of Development Economics, 87: 179-190. 
Coelli, T, and D. S. Prasada Rao. 2005. "Total factor productivity growth in agriculture: a Malmquist index analysis of 93 countries, 1980-2000.” Agricultural Economics, 32(1): 115-134.

DeLong, J. Bradford and Andrei Shleifer. 1993. "Princes and Merchants: City Growth before the Industrial Revolution.” Journal of Law and Economics 36(2): 671-702.

Diamond, Jared. 1997. Guns, Germs, and Steel. New York: Norton.

Djankov, S., R. La Porta, F. Lopez-de-Silanes and A. Shleifer. 2003. "The New Comparative Economics,” Journal of Comparative Economics 31(4), 595-619.

Dollar, David and Aart Kraay. 2003. “Institutions, Trade and Growth.” Journal of Monetary Economics 50(1): 133-62.

Easterly, William and Ross Levine. 2003. "Tropics, germs, and crops: how endowments influence economic development.” Journal of Monetary Economics 50(1): 3-39.

Engerman, Stanley, and Kenneth Sokoloff. 1991. "Factor Endowments, Institutions, and Differential Paths of Growth among New World Economies," in Stephen Haber (ed.), How Latin America Fell Behind, Stanford, CA: Stanford University Press.

Fulginiti, L.E. and R. K. Perrin. 1993. "Prices and Productivity in Agriculture." Review of Economics and Statistics, 75 (3): 471-482.

Gardner, B. 2005. “Causes of rural economic development” Agricultural Economics, 2005, 32 (1): 21-41.

Glaeser, E.., R. La Porta, F. Lopez-de-Silanes, and A.Shleifer. 2004. "Do Institutions Cause Growth?" Journal of Economic Growth, 9 (1): 271-303.

Glaeser, E., G. Ponzetto, and A. Shleifer. 2007, "Why Democracy Need Education?” Journal of Economic Growth, 12 (2): 77-99.

Hall, Robert E. and Charles I. Jones. 1999. "Why Do Some Countries Produce so Much More Output per Worker than Others?” Quarterly Journal of Economics, 114(1): 83-116.

Hayami, Y. and V. Ruttan.1985. “Agricultural Development: An International Perspective.” Baltimore, MD: John Hopkins University Press.

International Country Risk Guide. (Political Risk Services, East Syracuse, NY, 1996).

Jaggers, K. and M. Marshall, 2000. "Polity IV Project” Center for International Development and Conflict Management, University of Maryland.

Kaufmann, D., A. Kraay and M. Mastruzzi. 2003. “Governance Matters III: Updated Governance Indicators for 1996-02.” Working Paper Draft for comments. Washington, D.C.: World Bank.

Kaufmann, D., A. Kraay and P. Zoido-Lobatón. 2002. “Governance Matters II: Updated Governance Indicators for 2000-01” Working Paper No. 2772. World Bank Policy Research Department (February).

Knack, S. and P. Keefer. 1995. "Institutions and Economic Performance: CrossCountryTests Using Alternative Measures.” Economics and Politics 7(3): 207-27.

La Porta, R., F. Lopez-de-Silanes, A. Shleifer, and R. Vishny. 1997. "Legal Determinants of External Finance,” Journal of Finance 52(3), 1131-1150.

La Porta, R., F. Lopez-de-Silanes, A. Shleifer, and R. Vishny. 1998. "Law and Finance,” Journal of Political Economy 106(6), 1113-1155.

La Porta, R., F. Lopez-de-Silanes, A. Shleifer, and R. Vishny. 1999. “The Quality of Government,” Journal of Law, Economics, and Organization 15(1) 222-79. 
La Porta, R., F. Lopez-de-Silanes, C. Pop-Eleches and A. Shleifer. 2004. “Judicial Checks and Balances.” Journal of Political Economy 112(2), 445-470.

Lipset, Seymour M. 1960. Political Man: The Social Basis of Modern Politics. New York: Doubleday.

Ludena C., T. Hertel, P. Preckel, K. Foster, A. Nin. 2007. "Productivity growth and convergence in crop, ruminant, and nonruminant production: measurement and forecasts.” Agricultural Economics, 37(1): 1 - 17.

Mauro, Paolo, 1995, "Corruption and Growth," Quarterly Journal of Economics, 110: 681-712.

Montesquieu, Charles de Secondat. 1748. The Spirit of the Laws. Paris.

Mulligan, Casey, Ricard Gil, and Xavier Sala-i-Martin. 2004. "Do Democracies Have Different Public Policies than Nondemocracies?” Journal of Economic Perspectives 18(1): 51-74.

North, Douglass C. 1990. Institutions, Institutional Change, and Economic Performance. Cambridge: Cambridge University Press.

North, Douglass C. 1981. Structure and Change in Economic History. New York: Norton \& Co.

North, Douglass C. and Robert P. Thomas. 1973. The Rise of the Western World: A New Economic History. Cambridge: Cambridge University Press.

Papaioannou, Elias and Gregorios Siourounis. 2008a. "Democratization and Growth", Economic Journal, 118(10): 1520-15551.

Papaioannou, Elias and Gregorios Siourounis. 2008b. "Economic and Social Factors Driving the Third Wave of Democratization", Journal of Comparative Economics, 36( 3): 365-387.

Persson, Torsten and Guido Tabellini. 2003. The Economic Effects of Constitutions. Cambridge, Mass.: MIT Press.

Persson, Torsten, and Guido Tabellini. 2006a. "Democracy and Development: The Devil in the Details", American Economic Review Papers and Proceedings, 99(2): 319314.

Persson, Torsten, and Guido Tabellini. 2006b. "Democratic Capital: The Nexus of Economic and Political Change.” National Bureau of Economic Research (Cambridge, MA), Working Paper 12175.

Persson, Torsten, and Guido Tabellini. 2007."The Growth Effect of Democracy: Is It Heterogeneous and How Can It Be Estimated?" in Institutions and Economic Performance, (ed.) Elhanan Helpman, Harvard University Press, Cambridge, MA.

Persson, Torsten, and Guido Tabellini. 1994. "Is Inequality Harmful for Growth? Theory and Evidence." American Economic Review, 84 (3): 600-621.

Pfeiffer, L. M. 2003 "Agricultural productivity growth in the Andean community.” American Journal of Agricultural Economics, 85 (5): 1335-1341.

Pritchett, Lant. 2001. "Where has all the education gone?” World Bank Economic Review 15(3): 367-391.

Przeworski, Adam. 2004a. "The Last Instance: Are Institutions the Primary Cause of Economic Development?” European Journal of Sociology 45(2): 165-188.

Przerworski, Adam. 2004b. “Georgraphy vs Institutions Revisited: Were Fortuntes Reversed?”.Mimeo, New York University. 
Rajan, R. and L. Zingales. 2006. “The Persistence of Underdevelopment: Institutions, Human Capital, or constituencies?” NBER WP 12093, National Bureau of Economic Research, Cambridge, MA.

Rodrik, Dani, Arvind Subramanian and Francesco Trebbi, 2004. "Institutions Rule: The Primacy of Institutions over Geography and Integration in Economic Development.” Journal of Economic Growth, 9 (2): 131-165.

Smith, A. 1976 (1776). An Inquiry in to the Nature and Causes of the Wealth of Nations, edited by E. Canaan. Chicago, Ill.: University of Chicago Press.

World Bank. World Development Indicators. Washington DC, 2005. 
Table 1. Correlations of Measures of Institutions with Productivity

Log GDP pc (2000)
Executive constraints
(60-00)
Expropriation risk (82-97)
Autocracy - Alvarez
(60-90)
Government
effectiveness (98-00)
Judicial independence
(95)
Constitutional review
(95)
Plurality (75-00)
Proportional
representation (75-00)
Log TFP level 2000 (Rao)
Log Ag output per ag
worker (2000)

1.00

$0.71-1.00$

$\begin{array}{lll}0.79 & 0.64 \quad 1.00\end{array}$

$\begin{array}{llll}-0.74 & -0.86 & -0.69 & 1.00\end{array}$

$\begin{array}{lllll}0.79 & 0.63 & 0.83 & -0.59 & 1.00\end{array}$

$\begin{array}{lllll}0.03 & 0.35 & 0.26 & -0.19 & 0.30\end{array}$

1.00

$\begin{array}{lllllll}-0.06 & 0.19 & 0.12 & -0.03 & 0.05 & 0.22 & 1.00\end{array}$

$\begin{array}{lllllll}-0.25 & -0.35 & -0.17 & 0.24 & -0.19 & -0.10 & 0.00\end{array}$

1.00

$\begin{array}{llll}0.30 & 0.32 & 0.23 & -0.22\end{array}$

$\begin{array}{llll}0.59 & 0.48 & 0.57 & -0.52\end{array}$

0.91

0.65

0.68

$\begin{array}{lllll}0.21 & -0.17 & 0.13 & -0.59 & 1.00 \\ 0.58 & \mathbf{0 . 0 9} & \mathbf{0 . 1 0} & -\mathbf{0 . 1 1} & \mathbf{0 . 1 4} \\ & & & & \\ \mathbf{0 . 7 5} & \mathbf{0 . 1 6} & -\mathbf{0 . 0 2} & -\mathbf{0 . 2 9} & \mathbf{0 . 3 0}\end{array}$

1.00

$-0.68$

0.66 
Table 2. Agricultural output growth, Human Capital and Political Institutions (st. errors in parentheses)

\begin{tabular}{|c|c|c|c|c|c|c|c|c|c|}
\hline \multicolumn{10}{|c|}{ Dependent Variable: Growth of Ag Output per Ag worker, 1961-2001, FAO (\%) } \\
\hline $\log \mathrm{Ag}$ & -0.64415 & -0.62624 & -0.6521 & -0.62766 & -0.60029 & -0.62398 & -0.56785 & -0.64748 & -0.61662 \\
\hline $\begin{array}{l}\text { Output per } \\
\text { Ag worker }\end{array}$ & $(0.23274)^{\mathrm{a}}$ & $(0.23493)^{\mathrm{a}}$ & $(0.2333)^{\mathrm{a}}$ & $(0.23731)^{\mathrm{a}}$ & $(0.23914)^{b}$ & $(0.22361)^{\mathrm{a}}$ & $(0.2403)^{\mathrm{b}}$ & $(0.236)^{\mathrm{a}}$ & $(0.2332)^{\mathrm{a}}$ \\
\hline $\begin{array}{l}\text { log yrs of } \\
\text { schooling } \\
(1960)\end{array}$ & $\begin{array}{l}0.94004 \\
(0.34698)\end{array}$ & $\begin{array}{l}1.07622 \\
(0.39025)\end{array}$ & $\begin{array}{l}0.82299 \\
(0.37029)\end{array}$ & $\begin{array}{l}0.99893 \\
(0.371)^{a}\end{array}$ & $\begin{array}{l}1.05135 \\
(0.37201)\end{array}$ & $\begin{array}{l}0.99198 \\
(0.33394)\end{array}$ & $\begin{array}{l}0.89658 \\
(0.3472)\end{array}$ & $\begin{array}{l}0.93734 \\
(.0351)^{\mathrm{a}}\end{array}$ & $\begin{array}{l}0.89391 \\
(0.348)^{\mathrm{a}}\end{array}$ \\
\hline $\begin{array}{l}\text { Share of } \\
\text { population } \\
\text { living in } \\
\text { temp. zone } \\
\text { (1995) }\end{array}$ & $\begin{array}{l}2.55031 \\
(0.50645)\end{array}$ & $\begin{array}{l}2.59264 \\
(0.51167)\end{array}$ & $\begin{array}{l}2.27405 \\
(0.59001)\end{array}$ & $\begin{array}{l}2.59779 \\
(0.52046)\end{array}$ & $\begin{array}{l}2.78602 \\
(0.57912)\end{array}$ & $\begin{array}{l}2.47643 \\
(0.48735)\end{array}$ & $\begin{array}{l}2.49103 \\
(0.5064)\end{array}$ & $\begin{array}{l}2.54819 \\
(0.512){ }^{\mathrm{a}}\end{array}$ & $\begin{array}{l}2.45238 \\
(0.512)^{a}\end{array}$ \\
\hline Executive & & 0.10445 & & & & & & & \\
\hline $\begin{array}{l}\text { Constraints } \\
1960-2000\end{array}$ & & $(0.05461)^{b}$ & & & & & & & \\
\hline $\begin{array}{l}\text { Expropriation } \\
\text { risk (1982- } \\
\text { 1997) }\end{array}$ & & & $\begin{array}{l}0.15824 \\
(0.0725)\end{array}$ & & & & & & \\
\hline Autocracy -- & & & & -0.20869 & & & & & \\
\hline $\begin{array}{l}\text { Alvarez } \\
(1960-1990)\end{array}$ & & & & $(0.12553)^{\mathrm{C}}$ & & & & & \\
\hline Government & & & & & 0.26561 & & & & \\
\hline $\begin{array}{l}\text { effectiveness } \\
(1998-2000)\end{array}$ & & & & & $(0.1318)^{b}$ & & & & \\
\hline $\begin{array}{l}\text { Judicial } \\
\text { independence } \\
\text { (1995) }\end{array}$ & & & & & & $\begin{array}{c}-1.25143 \\
(1.57432)\end{array}$ & & & \\
\hline $\begin{array}{l}\text { Constitutional } \\
\text { review (1995) }\end{array}$ & & & & & & & $\begin{array}{l}0.83068 \\
(0.6957)\end{array}$ & & \\
\hline $\begin{array}{l}\text { Plurality } \\
(1975-2000)\end{array}$ & & & & & & & & $\begin{array}{l}-0.06423 \\
(0.3316)\end{array}$ & \\
\hline $\begin{array}{l}\text { Proportional } \\
\text { representation } \\
(1975-2000)\end{array}$ & & & & & & & & & $\begin{array}{l}0.40225 \\
(0.35121)\end{array}$ \\
\hline Observations & 48 & 48 & 48 & 48 & 48 & 48 & 48 & 48 & 48 \\
\hline $\mathrm{R}^{2}$ & 0.5703 & 0.5762 & 0.5786 & 0.5726 & 0.5774 & 0.6130 & 0.4208 & 0.5707 & 0.5830 \\
\hline
\end{tabular}

Level of Significance : 1\% (a), 5\% (b) , 10\% (c) 
Table 3. Agricultural TFP growth , Human Capital and Political Institutions (st. errors in parenthesis)

\begin{tabular}{|c|c|c|c|c|c|c|c|c|c|}
\hline \multicolumn{10}{|c|}{ Dependent Variable: TFP growth $1970-2001$ (\%, Alauddin, Headey, Rao) } \\
\hline $\begin{array}{l}\text { log TFP level } \\
\text { in } 1970 \text { Rao }\end{array}$ & $\begin{array}{l}-0.16626 \\
(0.07945)\end{array}$ & $\begin{array}{c}-0.16045 \\
(0.08160) \mathrm{b}\end{array}$ & $\begin{array}{c}-0.16257 \\
(0.08072)\end{array}$ & $\begin{array}{l}-0.15904 \\
(0.08119)\end{array}$ & $\begin{array}{l}-0.17548 \\
(0.08011)\end{array}$ & $\begin{array}{l}-0.16959 \\
(0.07988) b\end{array}$ & $\begin{array}{c}-0.16730 \\
(0.08041) b\end{array}$ & $\begin{array}{l}-0.16594 \\
(0.08038)\end{array}$ & $\begin{array}{l}-0.16700 \\
(0.08012)\end{array}$ \\
\hline $\begin{array}{l}\text { log yrs of } \\
\text { schooling }\end{array}$ & $\begin{array}{l}0.16831 \\
(0.04819)\end{array}$ & $\begin{array}{l}0.15279 \\
(0.06292)\end{array}$ & $\begin{array}{l}0.15728 \\
(0.05563)\end{array}$ & $\begin{array}{c}0.15120 \\
(0.05792)\end{array}$ & $\begin{array}{l}0.13861 \\
(0.05741)\end{array}$ & $\begin{array}{c}0.17407 \\
(0.04891)\end{array}$ & $\begin{array}{l}0.16718 \\
(0.04891)^{a}\end{array}$ & $\begin{array}{l}0.16903 \\
(0.04902){ }^{a}\end{array}$ & $\begin{array}{l}0.16995 \\
(0.04869)\end{array}$ \\
\hline $\begin{array}{l}\text { Share of } \\
\text { population }\end{array}$ & $\begin{array}{c}0.10244 \\
(0.08727)\end{array}$ & $\begin{array}{l}0.09710 \\
(0.08918)\end{array}$ & $\begin{array}{l}0.07909 \\
(0.10499)\end{array}$ & $\begin{array}{l}0.08992 \\
(0.09095)\end{array}$ & $\begin{array}{l}0.04908 \\
(0.10371)\end{array}$ & $\begin{array}{l}0.09839 \\
(0.08777)\end{array}$ & $\begin{array}{l}0.10267 \\
(0.08821)\end{array}$ & $\begin{array}{l}0.10300 \\
(0.08835)\end{array}$ & $\begin{array}{l}0.10908 \\
(0.08889)\end{array}$ \\
\hline $\begin{array}{l}\text { living in } \\
\text { temp. zone } \\
\text { (1995) }\end{array}$ & & & & & & & & & \\
\hline Executive & & 0.00971 & & & & & & & \\
\hline $\begin{array}{l}\text { Constraints } \\
1960-2000\end{array}$ & & $(0.0054)^{b}$ & & & & & & & \\
\hline Expropriation & & & 0.01302 & & & & & & \\
\hline $\begin{array}{l}\text { risk (1982- } \\
1997)\end{array}$ & & & $(0.00318)^{a}$ & & & & & & \\
\hline Autocracy -- & & & & -0.04315 & & & & & \\
\hline $\begin{array}{l}\text { Alvarez } \\
(1960-1990)\end{array}$ & & & & $(0.02795)^{\mathrm{C}}$ & & & & & \\
\hline Government & & & & & 0.05345 & & & & \\
\hline $\begin{array}{l}\text { effectiveness } \\
(1998-2000)\end{array}$ & & & & & $(0.0256)^{b}$ & & & & \\
\hline $\begin{array}{l}\text { Judicial } \\
\text { independence } \\
\text { (1995) }\end{array}$ & & & & & & $\begin{array}{l}-0.08776 \\
(0.10952)\end{array}$ & & & \\
\hline $\begin{array}{l}\text { Constitutional } \\
\text { review (1995) }\end{array}$ & & & & & & & $\begin{array}{l}-0.03137 \\
(0.12428)\end{array}$ & & \\
\hline $\begin{array}{l}\text { Plurality } \\
\text { (1975-2000) }\end{array}$ & & & & & & & & $\begin{array}{l}0.00816 \\
(0.06031)\end{array}$ & \\
\hline $\begin{array}{l}\text { Proportional } \\
\text { representation } \\
(1975-2000)\end{array}$ & & & & & & & & & $\begin{array}{l}-0.03396 \\
(0.06442)\end{array}$ \\
\hline Observations & 48 & 48 & 48 & 48 & 48 & 48 & 48 & 48 & 48 \\
\hline R Square & 0.4199 & 0.4220 & 0.4222 & 0.4239 & 0.4320 & 0.4285 & 0.4208 & 0.4202 & 0.4237 \\
\hline
\end{tabular}


Table 4. Agricultural Growth, Initial Human Capital, and Initial Constraints on the Executive

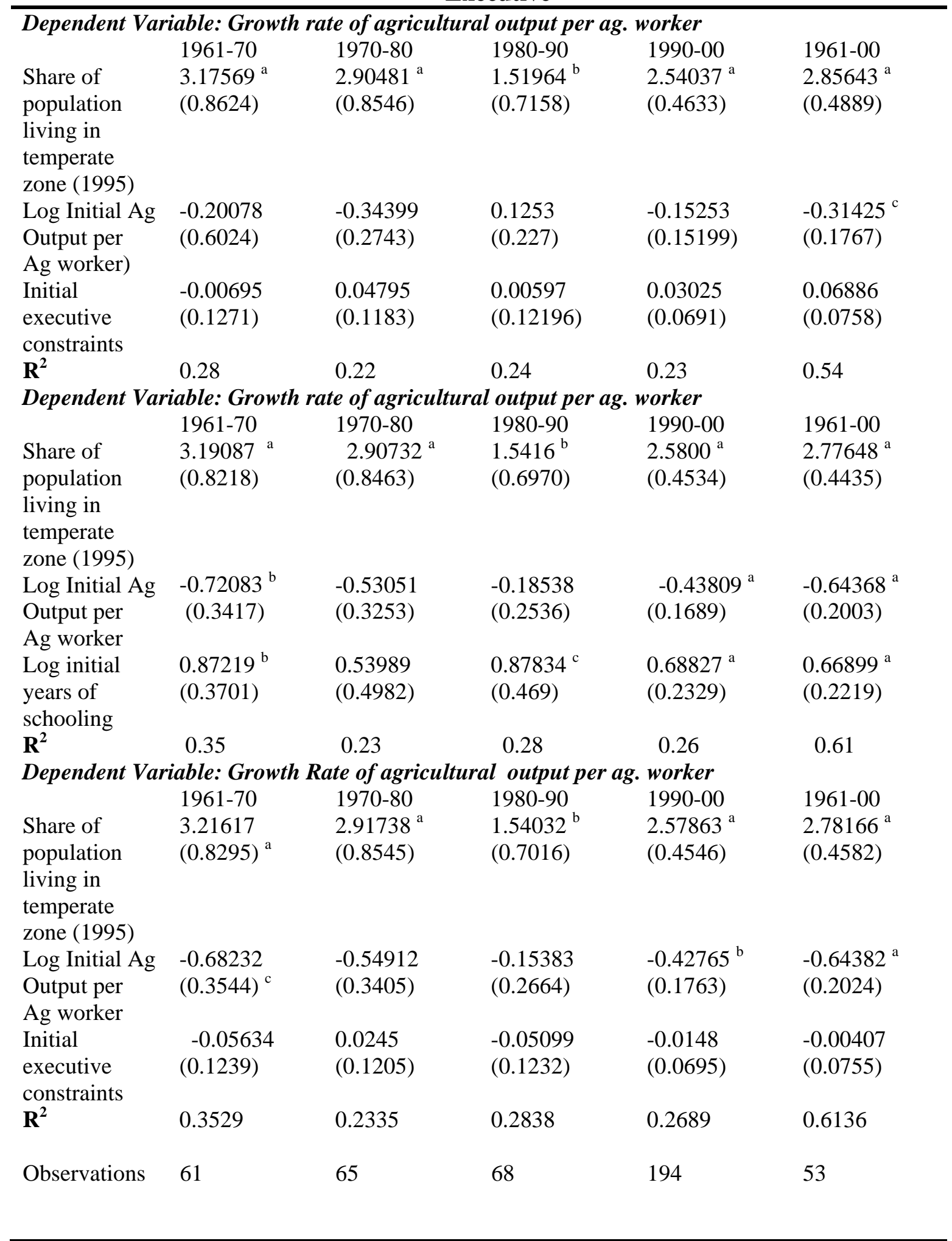

Significance Level: 1\% (a), 5\% (b), 10\% (c). Standard errors in parentheses. 
Table 5. TFP Growth, Initial Human Capital, and Initial Constraints on the Executive

\begin{tabular}{|c|c|c|c|c|}
\hline \multicolumn{5}{|c|}{ Dependent Variable: Growth rate of TFP, per decade and whole period } \\
\hline & $1970-80$ & $1980-90$ & $1990-00$ & $1971-01$ \\
\hline Share of & 0.02359 & 0.08952 & 0.10531 & $0.18643^{b}$ \\
\hline population & $(0.0507)$ & $(0.0605)$ & $(0.0759)$ & $(0.0846)$ \\
\hline \multicolumn{5}{|l|}{$\begin{array}{l}\text { living in } \\
\text { temperate zone } \\
\text { (1995) }\end{array}$} \\
\hline Log Initial TFP & $-0.09593^{\mathrm{C}}$ & $0.10095^{c}$ & $0.26873^{a}$ & $-0.16473^{c}$ \\
\hline Level (Rao) & $(0.0504)$ & $(0.0517)$ & $(0.0679)$ & $(0.0932)$ \\
\hline Initial executive & 0.01301 & $0.02212^{b}$ & 0.01246 & 0.04124 \\
\hline constraints & $(0.009)$ & $(0.0104)$ & $(0.0149)$ & $(0.1583)$ \\
\hline $\mathbf{R}^{2}$ & 0.12 & 0.25 & 0.39 & 0.36 \\
\hline \multicolumn{5}{|c|}{ Dependent Variable: Growth rate of TFP, per decade and whole period } \\
\hline & $1970-80$ & $1980-90$ & $1990-00$ & 1971-01 \\
\hline Share of & -0.04418 & -0.00660 & 0.02357 & 0.12172 \\
\hline population & $(0.0495)$ & $(0.0633)$ & $(0.0765)$ & $(0.0867)$ \\
\hline \multicolumn{5}{|l|}{$\begin{array}{l}\text { living in } \\
\text { temperate zone } \\
\text { (1995) }\end{array}$} \\
\hline Log Initial TFP & $-0.11340^{b}$ & 0.05782 & $0.21681^{\mathrm{a}}$ & $-0.20441^{b}$ \\
\hline Level (Rao) & $(0.0459)$ & $(0.0496)$ & $(0.0674)$ & $(0.0865)$ \\
\hline Log initial & $0.07687^{\mathrm{a}}$ & $0.1403^{a}$ & $0.13746^{\mathrm{a}}$ & $0.12921^{\mathrm{a}}$ \\
\hline $\begin{array}{l}\text { years of } \\
\text { schooling }\end{array}$ & $(0.0212)$ & $(0.0355)$ & $(0.0508)$ & $(0.0376)$ \\
\hline $\mathbf{R}^{2}$ & 0.26 & 0.36 & 0.44 & 0.41 \\
\hline \multicolumn{5}{|c|}{ Dependent Variable: Growth rate of TFP, per decade and whole period } \\
\hline & $1970-80$ & $1980-90$ & $1990-00$ & $1970-01$ \\
\hline Share of & -0.04634 & -0.01180 & 0.02975 & 0.07160 \\
\hline population & $(0.0516)$ & $(0.0642)$ & $(0.0785)$ & $(0.0891)$ \\
\hline \multicolumn{5}{|l|}{$\begin{array}{l}\text { living in } \\
\text { temperate zone } \\
\text { (1995) }\end{array}$} \\
\hline Log Initial TFP & -0.11215 & 0.05781 & $0.21862^{\mathrm{a}}$ & $-0.16551^{\mathrm{c}}$ \\
\hline Level (Rao) & $(0.0469)^{b}$ & $(0.0498)$ & $(0.0679)$ & $(0.0873)$ \\
\hline Initial executive & 0.00150 & 0.00679 & -0.00650 & $0.02814^{\mathrm{c}}$ \\
\hline constraints & $(0.0091)$ & $(0.0108)$ & $(0.0161)$ & $(0.0155)$ \\
\hline Log initial & 0.07536 & $0.12939^{a}$ & $0.14816^{\mathrm{a}}$ & 0.1083 \\
\hline $\begin{array}{l}\text { years of } \\
\text { schooling }\end{array}$ & $(0.0233)^{\mathrm{a}}$ & $(0.0367)$ & $(0.05758)$ & $(0.3851)$ \\
\hline $\mathbf{R}^{2}$ & 0.26 & 0.37 & 0.44 & 0.45 \\
\hline Observations & 61 & 65 & 68 & 53 \\
\hline
\end{tabular}

Significance Level: 1\% (a), 5\% (b), 10\% (c). Standard errors in parentheses. 
Table 6. Instrumenting Human Capital and Executive Constraints, Agricultural growth (IV)

Dependent Variable: Log Agricultural Output per ag. worker in 2000

(1)

Years of schooling (1960-

2000)

Executive constraints (1960-

2000)

Share of Population living in

temperate zone

Observations

R Square $0.858602^{\mathrm{a}}$

$(0.225)$

$-0.22504$

(0.212)

$-0.91792$

(1.0804)

56

0.68
(2)

$0.800253^{\mathrm{a}}$

$(0.237)$

$-0.28133$

(0.227)

$-0.49964$

(1.044)

65

Significance Level: $1 \%$ (a), $5 \%$ (b), $10 \%$ (c). Standard errors in parentheses.

Instruments: (1)share of population living in temperate zone, log settler mortality, French legal origin (2) share of population living in temperate zone, log population density in 1500, French legal origin

Table 7. Instrumenting Human Capital and Executive Constraints, TFP (IV)

Dependent Variable: Log TFP in 2000

$(1)$

$0.234692^{\mathrm{a}}$

(0.0945)

$-0.14975$

(0.141)

$-0.77798$

(0.652)

44

0.42
(2)

$0.249966^{\mathrm{b}}$

(0.114)

$-0.20555$

$(0.163)$

$-0.68405$

$(0.741)$

49

R Square

Significance Level: $1 \%$ (a), 5\% (b), 10\% (c). Standard errors in parentheses.

Instruments: (1)share of population living in temperate zone, log settler mortality, French legal origin (2) share of population living in temperate zone, log population density in 1500, French legal origin 
Table 8. Timing regressions of Schooling on Institutions (Output per worker)

\begin{tabular}{|c|c|c|c|c|}
\hline \multicolumn{5}{|c|}{ Dependent variable: 5 -year change in years of schooling $(t, t+5)$} \\
\hline Years of & $-0.34796^{\mathrm{a}}$ & $-0.35177^{\mathrm{a}}$ & $-0.35262^{\mathrm{a}}$ & $-0.34616^{a}$ \\
\hline schooling (t) & $(0.0852)$ & $(0.0844)$ & $(0.0853)$ & $(0.0847)$ \\
\hline $\log$ Ag output & $0.77758^{\mathrm{a}}$ & $0.78574^{\text {a }}$ & $0.78689^{\mathrm{a}}$ & $0.77088^{\mathrm{a}}$ \\
\hline per ag worker & $(0.2474)$ & $(0.7857)$ & $(0.2461)$ & $(0.2469)$ \\
\hline $\begin{array}{l}\text { Executive } \\
\text { constraints }\end{array}$ & $\begin{array}{l}-0.00752 \\
(0.0269)\end{array}$ & & & \\
\hline Autocracy $(\mathrm{t})$-- & & 0.00014047 & & \\
\hline Polity IV & & $(0.0164)$ & & \\
\hline Autocracy (t) -- & & & -0.00336 & \\
\hline Alvarez & & & $(0.0593$ & \\
\hline Democracy (t) & & & & $\begin{array}{l}-0.00929 \\
(0.01751)\end{array}$ \\
\hline Observations & 131 & 131 & 131 & 131 \\
\hline R Square & 0.4888 & 0.4883 & 0.4883 & 0.4901 \\
\hline
\end{tabular}

Table 9. Timing regressions of Institutions on Schooling (Output per worker)

\begin{tabular}{|c|c|c|c|c|}
\hline \multicolumn{5}{|c|}{ Dependent variable: 5 -year changes in political institutions $(t, t+5)$} \\
\hline & $\begin{array}{l}\text { Change } \\
\text { executive } \\
\text { constraints }\end{array}$ & $\begin{array}{l}\text { Change } \\
\text { autocracy, } \\
\text { Polity IV }\end{array}$ & $\begin{array}{l}\text { Change } \\
\text { autocracy, } \\
\text { Alvarez }\end{array}$ & $\begin{array}{l}\text { Change } \\
\text { democracy }\end{array}$ \\
\hline Years of & $0.88044^{\mathrm{b}}$ & $-1.32191^{\mathrm{a}}$ & $-0.33734^{b}$ & $1.12866^{\mathrm{b}}$ \\
\hline schooling (t) & $(0.3455)$ & $(0.4946)$ & $(0.1409)$ & $(0.5113)$ \\
\hline $\log$ Ag output & -0.37277 & 0.78419 & 0.13622 & -0.46739 \\
\hline per ag worker & $(1.003)$ & $(1.4525)$ & $(0.4067)$ & $(1.4909)$ \\
\hline $\begin{array}{l}\text { Executive } \\
\text { constraints (t) }\end{array}$ & $\begin{array}{l}-1.24427^{\mathrm{a}} \\
(0.1089)\end{array}$ & & & \\
\hline $\begin{array}{l}\text { Autocracy (t), } \\
\text { Polity IV }\end{array}$ & & $\begin{array}{l}-1.30207^{a} \\
(0.0962)\end{array}$ & & \\
\hline Autocracy (t), & & & $-1.31174^{\mathrm{a}}$ & \\
\hline Alvarez & & & $(0.0979)$ & \\
\hline Democracy $(\mathrm{t})$ & & & & $\begin{array}{l}-1.18130^{a} \\
(0.1058)\end{array}$ \\
\hline Observations & 131 & 131 & 131 & 131 \\
\hline R Square & 0.6974 & 0.7563 & 0.7443 & 0.7016 \\
\hline
\end{tabular}

Level of Significance : 1\% (a), 5\% (b) , 10\% (c). Standard errors in parentheses. 
Table 10. Timing regressions of Schooling on Institutions (TFP; $t, t+5$ )

\begin{tabular}{|c|c|c|c|c|}
\hline \multicolumn{5}{|c|}{ Dependent variable: 5-year change in years of schooling } \\
\hline Years of & $-0.19507^{\mathrm{a}}$ & $-0.20011^{\mathrm{a}}$ & $-0.19892^{\mathrm{a}}$ & $-0.19575^{\mathrm{a}}$ \\
\hline schooling (t) & $(0.0743)$ & $(0.0739)$ & $(0.0749)$ & $(0.0738)$ \\
\hline Log of TFP & -0.00533 & -0.01338 & -0.01713 & -0.00699 \\
\hline level Rao & $(0.22016)$ & $(0.2198)$ & $(0.2202)$ & $(0.2191)$ \\
\hline $\begin{array}{l}\text { Executive } \\
\text { constraints (t) }\end{array}$ & $\begin{array}{l}-0.01775 \\
(0.02845)\end{array}$ & & & \\
\hline Autocracy $(\mathrm{t})$-- & & 0.00721 & & \\
\hline Polity IV & & $(0.0173)$ & & \\
\hline $\begin{array}{l}\text { Autocracy (t) -- } \\
\text { Alvarez }\end{array}$ & & & $\begin{array}{l}0.00788 \\
(0.0631)\end{array}$ & \\
\hline Democracy (t) & & & & $\begin{array}{l}-0.01558 \\
(0.0185)\end{array}$ \\
\hline Observations & 131 & 131 & 131 & 131 \\
\hline R Square & 0.424 & 0.4225 & 0.4213 & 0.4264 \\
\hline
\end{tabular}

Table 11. Timing regressions of Institutions on Schooling (TFP; $t, t+5$ )

\begin{tabular}{|c|c|c|c|c|}
\hline \multicolumn{5}{|c|}{ Dependent variable: 5-year changes in political institutions } \\
\hline & $\begin{array}{l}\text { Change } \\
\text { executive } \\
\text { constraints }\end{array}$ & $\begin{array}{l}\text { Change } \\
\text { autocracy, } \\
\text { Polity IV }\end{array}$ & $\begin{array}{l}\text { Change } \\
\text { autocracy, } \\
\text { Alvarez }\end{array}$ & $\begin{array}{l}\text { Change } \\
\text { democracy }\end{array}$ \\
\hline Years of & $0.80513^{\mathrm{a}}$ & $-1.17091^{\mathrm{a}}$ & $-0.31021^{\mathrm{a}}$ & $1.03677^{\mathrm{b}}$ \\
\hline schooling (t) & $(0.2831)$ & $(0.4607)$ & (0.1163) & $(0.4201)$ \\
\hline Log of TFP & -0.59944 & 0.91017 & 0.13863 & -0.63372 \\
\hline level Rao & $(0.8389)$ & (1.2096) & $(0.3421)$ & $(1.246)$ \\
\hline $\begin{array}{l}\text { Executive } \\
\text { constraints (t) }\end{array}$ & $\begin{array}{l}-1.23144^{\mathrm{a}} \\
(0.1084)\end{array}$ & & & \\
\hline $\begin{array}{l}\text { Autocracy (t), } \\
\text { Polity IV }\end{array}$ & & $\begin{array}{l}-1.29028^{\mathrm{a}} \\
(0.0954)\end{array}$ & & \\
\hline $\begin{array}{l}\text { Autocracy (t), } \\
\text { Alvarez }\end{array}$ & & & $\begin{array}{l}-1.30655^{\mathrm{a}} \\
(0.0981)\end{array}$ & \\
\hline Democracy (t) & & & & $\begin{array}{l}-1.17389^{a} \\
(0.1052)\end{array}$ \\
\hline Observations & 131 & 131 & 131 & 131 \\
\hline R Square & 0.6988 & 0.7572 & 0.7445 & 0.7022 \\
\hline
\end{tabular}


Table 12. Years of Schooling (1960) and Average Democracy Score, 19602000 (PolityIV)

\begin{tabular}{|c|c|c|c|c|c|}
\hline \multirow{2}{*}{ Years of schooling in 1960} & \multicolumn{2}{|l|}{ More } & \multicolumn{3}{|c|}{ Less } \\
\hline & Democracy $=10$ & $10>$ Democracy $>7$ & $7>=$ Democracy $>2$ & Democrac & countries \\
\hline Low $<2.7$ & 1 & 3 & 10 & 20 & 34 \\
\hline Intermediate $2.7<=$ yrs of schooling $<=5$ & 2 & 3 & 9 & 1 & 15 \\
\hline High $>5$ & 16 & 2 & 0 & 0 & 18 \\
\hline total & 19 & 8 & 19 & 21 & 67 \\
\hline
\end{tabular}

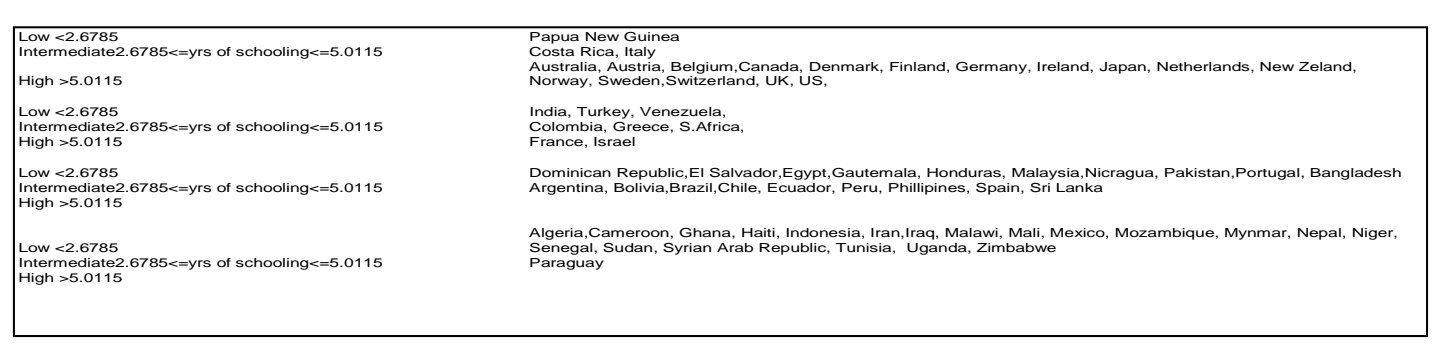


Table 13. Growth rates, Education, and Political Regimes

Panel A. Number of observations

\begin{tabular}{|l|l|l|l|l|l|}
\hline $\begin{array}{l}\text { Years of schooling in } \\
1960\end{array}$ & Democracy=10 & $10>$ Democracy $>7$ & $7>=$ Democracy $>2$ & Democracy<=2 & All countries \\
\hline Low $<2.6785$ & 26 & 126 & 407 & 810 & 1369 \\
\hline $\begin{array}{l}\text { Intermediate2.6785<=yrs } \\
\text { of schooling<=5.0115 }\end{array}$ & 82 & 126 & 378 & 42 & 628 \\
\hline High $>5.0115$ & 672 & 82 & & & 754 \\
\hline Total & 780 & 334 & 785 & 852 & 2751 \\
\hline
\end{tabular}

Panel B: Average within-country 10-year growth rate of ag. output per ag. worker

\begin{tabular}{|l|l|l|l|l|l|}
\hline $\begin{array}{l}\text { Years of schooling in } \\
1960\end{array}$ & Democracy $=10$ & $10>$ Democracy $>7$ & $7>=$ Democracy $>2$ & Democracy<=2 & All countries \\
\hline Low $<2.6785$ & 0.996369 & 2.092944 & 2.151907 & 1.787620 & 1.909155 \\
\hline $\begin{array}{l}\text { Intermediate2.6785<=yrs } \\
\text { of schooling<=5.0115 }\end{array}$ & 4.295646 & 3.086006 & 2.379521 & 2.063596 & 2.755240 \\
\hline High $>5.0115$ & 3.797412 & 4.996259 & & & 3.930618 \\
\hline Total & 3.702435 & 3.191171 & 2.259724 & 1.802952 & 2.675993 \\
\hline
\end{tabular}

Panel C: Mean standard deviation of the 10-year growth rate of ag. output per ag. worker across countries

\begin{tabular}{|l|l|l|l|l|l|}
\hline $\begin{array}{l}\text { Years of schooling in } \\
1960\end{array}$ & Democracy=10 & $10>$ Democracy $>7$ & $7>=$ Democracy $>2$ & Democracy<=2 & All countries \\
\hline Low $<2.6785$ & 1.008304 & 1.577902 & 1.996855 & 2.153675 & 2.023870 \\
\hline $\begin{array}{l}\text { Intermediate2.6785<=yrs } \\
\text { of schooling<=5.0115 }\end{array}$ & 1.708267 & 1.422043 & 2.033645 & 2.032442 & 1.961948 \\
\hline High $>5.0115$ & 1.918543 & 1.664618 & & & 1.919169 \\
\hline Total & 1.959768 & 1.881156 & 2.004133 & 2.134385 & 2.150289 \\
\hline
\end{tabular}


Table 14. Growth rates (TFP), Education, and Political Regimes

Panel A. Number of Oservations

\begin{tabular}{|l|l|l|l|l|l|}
\hline $\begin{array}{l}\text { Years of schooling in } \\
1960\end{array}$ & Democracy=10 & $10>$ Democracy $>7$ & $7>=$ Democracy $>2$ & Democracy<=2 & All countries \\
\hline Low $<2.6785$ & 26 & 126 & 407 & 810 & 1369 \\
\hline $\begin{array}{l}\text { Intermediate2.6785<=yrs } \\
\text { of schooling<=5.0115 }\end{array}$ & 82 & 126 & 378 & 42 & 628 \\
\hline High $>5.0115$ & 672 & 82 & & & 754 \\
\hline Total & 780 & 334 & 785 & 852 & 2751 \\
\hline
\end{tabular}

Panel B: Average within-country 10-year growth rate of TFP

\begin{tabular}{|l|l|l|l|l|l|}
\hline $\begin{array}{l}\text { Years of schooling in } \\
1960\end{array}$ & Democracy $=10$ & $10>$ Democracy $>7$ & $7>=$ Democracy $>2$ & Democracy $<=2$ & All countries \\
\hline Low $<2.6785$ & 0.025544 & 0.015339 & 0.022614 & 0.013373 & 0.016908 \\
\hline $\begin{array}{l}\text { Intermediate2.6785<=yrs } \\
\text { of schooling }<=5.0115\end{array}$ & 0.020843 & 0.020961 & 0.019427 & 0.019841 & 0.01995 \\
\hline High $>5.0115$ & 0.0341 & 0.042279 & & & 0.035009 \\
\hline Total & 0.032254 & 0.024182 & 0.021104 & 0.013727 & 0.022689 \\
\hline
\end{tabular}

Panel C: Mean standard deviation of the 10-year TFP growth rates across countries.

\begin{tabular}{|l|l|l|l|l|l|}
\hline $\begin{array}{l}\text { Years of schooling in } \\
1960\end{array}$ & Democracy $=10$ & $10>$ Democracy $>7$ & $7>=$ Democracy $>2$ & Democracy $<=2$ & All countries \\
\hline Low $<2.6785$ & 0.004908 & 0.016105 & 0.018976 & 0.019515 & 0.019126 \\
\hline $\begin{array}{l}\text { Intermediate2.6785<=yrs } \\
\text { of schooling }<=5.0115\end{array}$ & 0.010942 & 0.011079 & 0.017676 & 0.010873 & 0.015131 \\
\hline High $>5.0115$ & 0.019748 & 0.016743 & & & 0.019504 \\
\hline Total & 0.018946 & 0.017824 & 0.01832 & 0.019152 & 0.019905 \\
\hline
\end{tabular}




\section{Appendix 1. Definition and sources of variables.}

Executive constraints

Democracy

Autocracy -- Polity IV

Expropriation risk

Autocracy -- Alvarez

Government effectiveness

\section{Measures of institution}

A measure of the extent of institutionalized constraints on the decision making powers of chief executives. The variable takes seven different values: (1) Unlimited authority (there are no regular limitations on the executive's actions, as distinct from irregular limitations such as the threat or actuality of coups and assassinations); (2) Intermediate category; (3) Slight to moderate limitation on executive authority (there are some real but limited restraints on the executive); (4) Intermediate category; (5) Substantial limitations on executive authority (the executive has more effective authority than any accountability group but is subject to substantial constraints by them); (6) Intermediate category; (7) Executive parity or subordination (accountability groups have effective authority equal to or greater than the executive in most areas of activity). This variable ranges from one to seven where higher values equal a greater extent of institutionalized constraints on the power of chief executives. This variable is calculated as the average from 1960 through 2000 , or for specific years as needed in the tables. Source: Jaggers and Marshall (2000).

A measure of the degree of democracy in a given country based on: (1) the competitiveness of political participation; (2) the openness and competitiveness of executive recruitment; and (3) the constraints on the chief executive. The variable ranges from zero to ten, where higher values equal a higher degree of institutionalized democracy. This variable is calculated as the average from 1960 through 2000, or for specific years as needed in the tables. Source: Jaggers and Marshall (2000).

A measure of the degree of autocracy in a given country based on: (1) the competitiveness of political participation; (2) the regulation of political participation; (3) the openness and competitiveness of executive recruitment; and (4) constraints on the chief executive. This variable ranges from zero to ten where higher values equal a higher degree of institutionalized autocracy. This variable is calculated as the average from 1960 through 2000, or for specific years as needed in the tables. Source: Jaggers and Marshall (2000).

Risk of "outright confiscation and forced nationalization" of property. This variable ranges from zero to ten where higher values are equals a lower probability of expropriation. This variable is calculated as the average from 1982 through 1997, or for specific years as needed in the tables. Source: International Country Risk Guide at http://www.countrydata.com/datasets/.

This variable classifies regimes based on their degree of autocracy. Democracies are coded as 0 , bureaucracies (dictatorships with a legislature) are coded as 1 and autocracies (dictatorship without a legislature) are coded as 2 . Transition years are coded as the regime that emerges afterwards. This variable ranges from zero to two where higher values equal a higher degree of autocracy. This variable is measured as the average from 1960 through 1990; or for specific years as needed in the tables. Source: Alvarez et al. (2000).

This variable measures the quality of public service provision, the quality of the bureaucracy, the competence of civil servants, the independence of the civil service from political pressures, and the credibility of the government's commitment to policies. The main focus of this index is on "inputs" required for the government to be able to produce and implement good policies and deliver public goods. This variable ranges from - 2.5 to 2.5 where higher values equal higher government effectiveness. This variable is measured as the average from 1998 through 2000. Source: Kaufman et al. (2003). 
Judicial independence is computed as the sum of three variables. The first measures the tenure of Supreme Court judges (highest court in any country) and takes a value of 2 - if tenure is lifelong, 1 - if tenure is more than six years but not lifelong, and 0 - if tenure is less than six years. The second measures the tenure of the highest ranked judges ruling on administrative cases and takes a value of 2 - if tenure is lifelong, 1 - if tenure is more than six years but not lifelong, 0 - if tenure is less than six years. The third measures the existence of case law and takes a value of 1 if judicial decisions in a given country are a source of law and 0 otherwise. The variable is normalized from zero to one where higher values equal a higher degree of judicial independence. This variable is measured as of 1995. Source: La Porta et al. (2004).

Constitutional review

Plurality

Proportional representation

average from 1975 through 2000. Source: Beck et al. (2001).

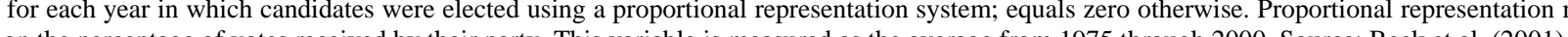

Other variables

Share of population living in Percentage of a country's population in Koeppen-Geiger temperate zone in 1995. Source: Center for International Development, Geography Data Sets. Found online at: temperate zone http://www2.cid.harvard.edu/ciddata/geographydata.htm\#General\%20measures\%20of\%20geography.

Log settler mortality

Log of the mortality rate faced by European settlers at the time of colonization. Source: Acemoglu, et al. (2001)

Population density in 1500

Years of schooling the review the constitutionality of laws in a given country. The variable takes three values: 2- if there is full review of constitutionality of laws, 1 - if there is limited review of country. One point each is given if the approval of the majority of the legislature, the chief of state and a referendum is necessary in order to change the constitution. An additional point is given for each of the following: if a supermajority in the legislature (more than $66 \%$ of votes) is needed, if both houses of the legislature have to approve, if the legislature has to approve the amendment in two consecutive legislative terms or if the approval of a majority of state legislature is required. This variable is normalized from zero to one where higher values equal a higher degree of constitutional review by the courts. This variable is measured as of 1995. Source: La Porta et al. (2004).
Years of schooling of the total population aged over 25. This variable is constructed as the average from 1960 through 2000; or for specific years as needed in the tables. Source: Barro, Robert J. and Jong-Wha Lee, International Data on Educational Attainment: Updates and Implications. Source: Barro and Lee (2000) Data posted on http://www.cid.harvard.edu/ciddata/ciddata.html 
Agricultural Output

Agricultural workers

TFP in agriculture

Legal origin

GDP per capita
Value of agricultural production in 1989-1991 international dollars. Source: provided by Ludena et al. (Not in La Porta's web site)

Number of workers employed in agriculture. Source: provided by Ludena et al. (Not in La Porta’s web site)

Estimated by Alauddin et al. using a translog distance frontier. Source: from the authors. (not in La Porta’s web site)

Identifies the legal origin of the company law or commercial code of each country (English, French, Socialist, German, and Scandinavian). Source: La Porta et al. (1999).

Gross domestic product over population. Source: Aten et al. (2002). Data available on-line at: http://pwt.econ.upenn.edu/ (this paper uses data from the 04-06-2003 version). GDP per capita for the 1870-1950 periods comes from Maddison (2003). 


\section{Endnotes.}

\footnotetext{
${ }^{1}$ There are numerous earlier studies of multi-country agricultural productivity growth, partial and multi factor, that I am not explicitly mentioning. The legacy is very rich. A summary can be found in Hayami and Ruttan and Fulginiti and Perrin.

${ }^{2}$ Productivity is output per unit of input. Partial productivity indexes account for a subset of inputs in production, most commonly just one, i e. output per ha, output per worker. Multifactor or total factor productivity (TFP) indexes account for as many inputs as used in the production process.

${ }^{3}$ For example Singapore and the USSR are in the ten best in 1984 in terms of low expropriation risk. Also Iran, Syria, and Lybia are ranked among the best improved countries as their dictators had stayed away from expropriation.

${ }^{4}$ The country with the highest score here is Singapore, whose dictator is market-oriented and has chosen respect for private property.

${ }^{5}$ Results are more mixed for intermediate education than for low education. They are: $44 \%, 32 \%, 18 \%$, and $23 \%$. Still a concentration on autocratic leaders with longer tenures than democratic ones.

${ }^{6}$ See the discussion between Acemoglu and Glaeser in the Wall Street Journal on line (Econblog), March 13, 2007, "Is Democracy the Best Setting For Strong Economic Growth?”
} 